Chirurgia (2021) 116: 591-598

No. 5, September - October

Copyright $\odot$ Celsius

http://dx.doi.org/10.21614/chirurgia.116.5.591

\title{
"Fistura Score" as a Predictive Instrument for Anastomotic Leak
}

\author{
Constantin Budin ${ }^{1}$, Alexandru IIco ${ }^{2}$, Dănuț Vasile ${ }^{1,2}$, Dragoș Eugen Georgescu ${ }^{1,3^{*}}$, Daniel Staniloaie ${ }^{1,2}$ \\ "'Carol Davila" University of Medicine and Pharmacy, Bucharest, Romania \\ ${ }^{2} 1^{\text {st }}$ Department of General Surgery, University Emergency Hospital, Bucharest, Romania \\ ${ }^{3} 1^{\text {st }}$ Department of General Surgery, "Dr. I. Cantacuzino Clinical Hospital”, Bucharest, Romania
}

*Corresponding author:

Dragoș Eugen Georgescu, MD

$1^{\text {st }}$ Department of General Surgery

"Dr. I. Cantacuzino Clinical Hospital"

Bucharest, Romania

E-mail: gfdragos@yahoo.com

Abbreviations:

$\mathrm{AL}$ : anastomotic leak,

CKD: chronic kidney disease,

CHF: congestive heart failure,

eGFR: estimated glomerular filtration

rate,

GIST: gastrointestinal stromal tumor,

AF: atrial fibrillation,

Se: sensibility,

Sp: specificity,

PPV: predictive positive value,

PNV: predictive negative value,

OR: odds ratio,

USP: United States Pharmacopeia.

Received: 20.07.2021

Accepted: 27.09.2021

\section{Rezumat}

“FISTULA SCORE" - instrument predictiv pentru fistula de anastomoză

Introducere: $\mathrm{O}$ anastomoză patentă este rezultatul tehnicii chirurgicale adaptată la terenul pacientului. Cunoscându-se posibilele efecte dramatice pe care le poate avea o fistulă postanastomotică asupra pacientului şi a personalului medical, identificarea factorilor de risc pentru apariția acesteia reprezintă o prioritate în alegerea tehnicii chirurgicale adoptate.

Material şi Metode: Folosirea de scoruri multifactoriale permite cuantificarea pacientului la risc, creşterea gradului de suspiciune şi inițierea precoce a tratamentului adecvat. A fost studiată corelația dintre diverşi potențiali factori de risc şi prezența unei fistule de anastomoză. FISTULA SCORE reprezintă un instrument de departajare a riscului ce include 12 variabile (clinice, paraclinice, terapeutice), cu o semnificație statistică bună (Se $=79.5 \%, \mathrm{Sp}=90.2 \%)$.

Rezultate:Din cei 508 pacienți incluşi în studiu, 39 au dezvoltat fistule de anastomoză $(7.68 \%$, 95\% CI: 5.67-10.32), apărute în zilele 2-10 postoperator, cu o valoare medie de 6 zile. "FISTULA SCORE" se bazează pe atribuirea riscului pentru fiecare variabilă studiată, având scopul de a identifica pacienți ce pot dezvolta fistule de anstomoză şi în unele situatii de a schimba strategia terapeutică sau chirurgicală. În grupul de pacienți cu fistula de anastomoză, scorul mediu a fost de 5.06 puncte (DS=1.95 puncte), în timp ce în grupul fără fistule a fost de 1.57 puncte (DS=1.61 puncte).

Concluzii: Riscul de fistulă de anastomoză trebuie apreciat şi 
cuantificat cu un sistem multivariabil de scor. "FISTULA SCORE" poate identifica, cu o semnificație statistică bună, pacienții la risc pentru fistule de anastomoză, modificînd managementul cazului, diminuând durata de spitalizare, costurile, mortalitate şi impactul psihologic asupra pacientului şi personalului medical.

Cuvinte cheie: anastomoză, fistulă, factori de risc, scor

\begin{abstract}
Introduction: A patent digestive anastomosis is not only the result of the surgery team experience, but also dependent on the patient's factors. Accepting the possible dramatic effects of an anastomotic leak, identification of risk factors remains a priority in case management.

Material and methods: Multifactorial assessment scores permit risk quantification, increase grade of suspicion and early management implementation. The correlation between diverse potential risk factors and anastomotic leak (AL) was studied. The identified risk factors were included in a predictive score system. FISTULA SCORE represents a feasible instrument based on 12 clinical, paraclinical and therapeutic variables, with good statistical significance $(\mathrm{Se}=79.5 \%, \mathrm{Sp}=90.2 \%$ ). Results: Anastomotic leaks (AL) were observed in 39 cases (7.68\%) out of 508 patients analysed, appearing in days $2-10$ after surgery, with a mean value of 6 days. FISTULA SCORE was based on attributed risks found in our study group for each factor and has the purpose to identify patients at risk for AL and, in some cases, to change the therapeutic or surgical strategy. In AL patients' group, the mean score was $5.06 \pm 1.95$ points, and in AL-free patients' group $-1.57 \pm 1.61$ points .

Conclusions: The risk for AL must be appreciated and quantified with a multivariable scoring system. FISTULA SCORE can identify, with a good statistical significance, patient at risk for AL, changing the management of case, reducing length of stay, costs, morbidities, mortality and psychological effects on patient and medical stuff.
\end{abstract}

Key words: anastomosis, anastomotic leak, risk factors, FISTULA SCORE

\section{Introduction}

An anastomosis in good conditions represents the best way to finish a resection in digestive surgery, for non-oncological, malignant or borderline pathologies, in children or adult patients $(1,2)$. Studied for a long time, a lot of technics of anastomosis were proposed, but not all of them can certainly eliminate the risk of leakage (AL) - the most severe complication of an anastomosis (3). The reported incidence in national and international studies can vary by author, differences based on surgery team experience, center profile, site of anastomosis $(4,5)$. We have to accept that AL is a reality and all patients with this complication are at risk for prolonged length of hospital stay, morbidities, poor long-term outcome and death $(6,7)$. The most frequent risk factors cited in literature are male sex, obesity, diabetes, advanced malignant disease, ASA score, perioperative blood loss or perioperative transfusion, long operation time, emergency operation and altered nutritional status $(8,9)$.

Identification of patients at increased risk for anastomotic dehiscence is imperative for surgical approach choice and early diagnosis of AL. AL result from an interrelation of a multitude of risk factors and multiple risk assessment scores were proposed (The REAL Score - Rectal Anastomotic Leak Score, mCLS - modified Colon Leakage Score, DIACOLE) (10-12). Unfortunately, none of these can identify or predict all cases of $\mathrm{AL}$ and other 
scoring systems with improved predictive power are needed.

\section{Materials and Methods}

A retrospective analysis of the medical records of a consecutive 508 patients who underwent surgical bowel resection for different pathologies, between January 2015 and December 2020, at $1^{\text {st }}$ Department of General Surgery of the University Emergency Hospital, Bucharest, was carried out. This study was approved by Ethics Committee of the Emergency University Hospital of Bucharest (Romania). Written informed consent was obtained from the patients prior to publication.

The inclusion criteria were: [1] both sexes, [2] age $\geq 18$ years, [3] benign or malignant pathologies, and [4] surgical procedure with at least one intestinal anastomosis. Conversely, the exclusion criteria were: [1] age $<18$ years, [2] surgical procedure without anastomosis (with end stoma only).

For each patient, data such as sex, age, place of origin, hospitalization regime, type of pathology, type and technique of the performed anastomosis, length of stay, associated pathologies, occurrence of AL and complications and various laboratory data (hemoglobin, protein status, serum calcium) were extracted from the records.

The diagnosis of $\mathrm{AL}$ was established by clinical examination, radiological examination, endoscopy or reoperation.

The characteristics of study group are described in Table 1.

The correlation between diverse potential risk factors (sex, age, nature of pathology, preoperative hemoglobin, necessity of blood transfusion, total proteins, albumin, blood calcium, obesity, cardiac arrythmias, congestive heart failure, atherosclerosis, diabetes, liver pathologies, renal failure, presence of peritonitis, gut obstruction, presence of metastasis, hemodynamic instability, type of admission, anastomosis technics) and AL was studied. The identified risk factors were included in a predictive score system.
Table 1. Description of study group

\begin{tabular}{llccl}
\hline Characteristics & & $\mathbf{n}$ & $\mathbf{\%}$ & IC (95\%) \\
\hline Sex & Male & 281 & 55.31 & $50.97-59.58$ \\
& Female & 227 & 44.69 & $40.42-49.03$ \\
\hline Place of origin & Urban & 325 & 63.98 & $59.71-68.03$ \\
& Rural & 183 & 36.02 & $31.97-40.29$ \\
\hline Age group (years) & $18-25$ & 6 & 1.18 & $0.54-2.55$ \\
& $25-34$ & 13 & 2.56 & $1.50-4.33$ \\
& $35-44$ & 23 & 4.53 & $3.04-6.70$ \\
& $45-54$ & 46 & 9.06 & $6.86-11.87$ \\
& $55-64$ & 129 & 25.39 & $21.80-29.35$ \\
& $65-74$ & 159 & 31.30 & $27.42-35.46$ \\
& $75-84$ & 115 & 22.64 & $19.21-26.47$ \\
& $>85$ & 17 & 3.35 & $2.10-5.29$ \\
\hline Admission & Emergency & 130 & 25.59 & $21.99-29.56$ \\
& Scheduled & 378 & 74.41 & $70.44-78.01$ \\
\hline Type of pathology & Benign & 114 & 22.44 & $19.03-26.27$ \\
& Malignant & 394 & 77.56 & $73.73-80.97$ \\
\hline Anastomotic leak & Yes & 39 & 7.68 & $5.67-10.32$ \\
& No & 469 & 92.32 & $89.68-94.33$ \\
\hline Death & Yes & 21 & 4.13 & $2.72-6.24$ \\
& No & 489 & 95.87 & $93.76-97.28$ \\
\hline
\end{tabular}

\section{Statistical Analysis}

Collected data were processed using statistical analysis programs Microsoft Excel 2016 and Epi Info $^{\text {TM }}$ 3.5.3 (https://www.cdc.gov/epiinfo/ index.html; Centers for Disease Control and Prevention; CDC). Continuous data (as age, hemoglobin level) were calculated as mean and standard deviation (SD). Data were compared between groups using two-tailed Student's t-test. Categorical data (as gender, necessity of blood transfusion) were analyzed using a chi-square test or Fisher's exact probability test. Differences were considered statistically significant at a probability value of $\mathrm{P}<0.05$. To determine whether a studied condition is a risk factor and to compare the magnitude of those factors for $\mathrm{AL}$ the odds ratio (OR) was used.

\section{Results}

Out of 508 patients, 281 were male (55.3\%) and 227 were female $(44.7 \%)$, with a mean age $65.5 \pm 12.9$ years.

The majority of anastomosis was made manually (423 anastomosis, 83.27\%), in a single plane (365 anastomosis, $87.11 \%$ ), with polypropylene (366 anastomosis, $87.35 \%$ ), 3-0 
USP (241 anastomosis, 57.66\%).

ALs were observed in 39 cases $(7.68 \%)$, appearing in days $2-10$ after surgery, with a mean value of 6 days. Almost a half of patients with AL were reoperated (18 cases, $46.15 \%)$.

General mortality in studied group was $4.13 \%$ ( 21 cases), greater in AL group ( 7 cases, $17.95 \%)$, versus non-AL group (14 cases, 2.99\%).

Malignant pathologies were the most common type (394 cases, 77.6\%), including malignant GISTs. Identified differences of occurrence of ALs were statistically insignificant between men (25 cases, 8.90\%) and women (14 cases, 6.17\%) $(\mathrm{P}=0.25)$, between patients with benign (114 patients, $5.3 \%)$ and malignant nature of pathology (394 patients, $8.3 \%)(\mathrm{P}=0.27)$, protein or albumin status $(\mathrm{P}=0.35$ and $\mathrm{P}=0.33)$. Emergency surgery was affected by $11.54 \%$ of AL incidence (95\% CI: $6.60-18.32)$, scheduled - by $6.35 \%$ incidence (95\% CI: 4.30-9.27) $(\mathrm{P}=0.05)$. There were no significant differences between hand sewn or mechanical anastomosis and $\mathrm{AL}$ incidence $(\mathrm{P}=0.51)$.

Mean hemoglobin $(\mathrm{Hb})$ level was $11.57 \pm$ $2.15 \mathrm{~g} / \mathrm{dL}$, smaller in AL group (10.18 \pm 2.05 $\mathrm{g} / \mathrm{dL})$ compared with non-AL group (11.69 \pm $2.12 \mathrm{~g} / \mathrm{dL})(\mathrm{P}=0.001)$.

Preoperative serum calcium level (Ca) was analyzed in 169 patients. The mean value was $8.67 \pm 0.91 \mathrm{mg} / \mathrm{dL}$ ), with $8.15 \pm 1.03 \mathrm{mg} / \mathrm{dL}$ in $\mathrm{AL}$ group and $8.75 \pm 0.92 \mathrm{mg} / \mathrm{dL}$ in non-AL group. In 67 of 169 patients (37.43\%) we found that Ca level was below $8.5 \mathrm{mg} / \mathrm{dL}$, including them in hypocalcemia group. Hypocalcemia was observed in 11 of 18 patients with $\mathrm{AL}$ (61.11\%) and in 56 of 161 patients without postoperative anastomotic dehiscence (34.78\%). In normal serum calcium level group $\mathrm{AL}$ occurred in $6.25 \%$ of cases ( 7 patients) and in $16.42 \%$ (11 cases) of cases in patients with hypocalcemia $(\mathrm{P}<0.001)$.

$\mathrm{AL}$ incidence in patients with advanced oncologic pathologies with presence of distant metastasis was $20.51 \%$ (8 cases), significantly greater than in patients without metastasis $(\mathrm{P}=0.002)$
Studying the medical histories, we observed that presence of atherosclerotic disease, arrythmias, diabetes, liver diseases, obesity, chronic kidney disease or acute renal injury favor appearance of $\mathrm{AL}$ (Table 2).

Atherosclerosis was found in 136 patients (26.77\%), with no significant difference between sexes $(\mathrm{P}=0.21)$. AL was present in 28 patients of them $(20.59 \%)$. The incidence of $\mathrm{AL}$ in non-atherosclerotic patients was $2.96 \%$ (11 cases). We conclude that atherosclerosis can be included in risk factors' list considered as a risk factor for $\mathrm{AL}(\mathrm{P}<0.001)$.

Sixty-eight patients were known or diagnosed de novo with diabetes (13.39\%), without significant differences between men and women $(\mathrm{P}=0.34)$. In this group ALs occurred in $17.65 \%$ of patients (12 cases), more frequent than in non-diabetic group of patients $(6.14 \%)$, differences being significant $(\mathrm{P}=0.003)$.

Atrial fibrillation (AF) was the preponderant heart arrythmia identified in this group (9.45\%). AL incidence in patients with AF was $20.83 \%$ and $6.30 \%$ in non-arrhythmic patients $(\mathrm{P}<0.001)$.

Presence of acute or chronic liver diseases negatively affect $\mathrm{AL}$ incidence $(17.07 \%$, vs. $6.85 \%)(\mathrm{P}=0.02)$

The same effect was observed in patients with congestive heart failure. AL incidence was $19.44 \%$ vs $6.78 \%(\mathrm{P}=0.006)$.

Anastomosis was made in 92 of patients with acute or subacute intestinal obstruction, more than a half of those for tumoral pathologies $(57.61 \%)$. AL was observed in 13 patients (14.13\%, 95\% CI: 7.74-22.95). Data analysis show that a patient with bowel obstruction is more exposed to $\mathrm{AL}$, comparing with patients without intestinal obstruction $(\mathrm{P}=0.01)$.

Presence of peritonitis was noted in 45 patients (8.86\%). Postoperative period was marked by ALs in 7 of them (15.56\%). The AL incidence in non-peritonitis patients was 6.91\% (32 patients). Comparing this data we conclude that peritonitis favor appearance of $\mathrm{AL}$ and can be included in the list of risk factors $(\mathrm{P}=0.037)$.

Hemodynamic instability (objected especially by hypotension, arrhythmias) was 
Table 2. Risk factors, associated incidence of $A L$ and statistical significance

\begin{tabular}{|c|c|c|c|c|c|c|}
\hline \multirow[t]{2}{*}{ Risk factor } & & \multicolumn{2}{|c|}{$\mathrm{AL}+$} & \multicolumn{2}{|c|}{ AL- } & \multirow[t]{2}{*}{$P^{*}$} \\
\hline & & $\mathrm{n}$ & $\%$ & $\mathbf{n}$ & $\%$ & \\
\hline Atherosclerosis & $\begin{array}{l}\text { Yes } \\
\text { No }\end{array}$ & $\begin{array}{l}28 \\
11\end{array}$ & $\begin{array}{c}20.59 \\
2.96\end{array}$ & $\begin{array}{l}108 \\
361\end{array}$ & $\begin{array}{l}79.41 \\
97.04\end{array}$ & $<0.001$ \\
\hline Diabetes & $\begin{array}{l}\text { Yes } \\
\text { No }\end{array}$ & $\begin{array}{l}13 \\
26\end{array}$ & $\begin{array}{c}18.84 \\
5.92\end{array}$ & $\begin{array}{c}56 \\
413\end{array}$ & $\begin{array}{l}81.16 \\
94.08\end{array}$ & 0.002 \\
\hline Atrial fibrillation & $\begin{array}{l}\text { Yes } \\
\text { No }\end{array}$ & $\begin{array}{l}10 \\
29\end{array}$ & $\begin{array}{c}20.83 \\
6.30\end{array}$ & $\begin{array}{c}38 \\
431\end{array}$ & $\begin{array}{l}79.17 \\
93.70\end{array}$ & $<0.001$ \\
\hline Liver disease & $\begin{array}{l}\text { Yes } \\
\text { No }\end{array}$ & $\begin{array}{c}7 \\
32\end{array}$ & $\begin{array}{c}17.07 \\
6.85\end{array}$ & $\begin{array}{c}34 \\
435\end{array}$ & $\begin{array}{l}82.93 \\
93.15\end{array}$ & 0.018 \\
\hline Obesity & $\begin{array}{l}\text { Yes } \\
\text { No }\end{array}$ & $\begin{array}{l}11 \\
28\end{array}$ & $\begin{array}{c}21.57 \\
6.13\end{array}$ & $\begin{array}{c}40 \\
429\end{array}$ & $\begin{array}{l}78.43 \\
93.87\end{array}$ & $<0.001$ \\
\hline Kidney disease & $\begin{array}{l}\text { Yes } \\
\text { No }\end{array}$ & $\begin{array}{c}9 \\
30\end{array}$ & $\begin{array}{c}32.14 \% \\
6.25 \%\end{array}$ & $\begin{array}{c}19 \\
450\end{array}$ & $\begin{array}{l}67.86 \% \\
93.75 \%\end{array}$ & $<0.01$ \\
\hline Metastasis & $\begin{array}{l}\text { Yes } \\
\text { No }\end{array}$ & $\begin{array}{c}8 \\
31\end{array}$ & $\begin{array}{c}20.51 \% \\
6.61 \%\end{array}$ & $\begin{array}{c}31 \\
438\end{array}$ & $\begin{array}{l}79.49 \% \\
93.39 \%\end{array}$ & 0.002 \\
\hline $\mathrm{Hb}<10 \mathrm{~g} / \mathrm{dL}$ & $\begin{array}{l}\text { Yes } \\
\text { No }\end{array}$ & $\begin{array}{l}15 \\
24\end{array}$ & $\begin{array}{c}14.02 \% \\
5.99 \%\end{array}$ & $\begin{array}{c}92 \\
377\end{array}$ & $\begin{array}{l}85.98 \% \\
94.01 \%\end{array}$ & 0.006 \\
\hline Hypocalcemia & $\begin{array}{l}\text { Yes } \\
\text { No }\end{array}$ & $\begin{array}{c}11 \\
7\end{array}$ & $\begin{array}{c}16.42 \% \\
6.25 \%\end{array}$ & $\begin{array}{c}56 \\
105\end{array}$ & $\begin{array}{l}83.58 \% \\
93.75 \%\end{array}$ & 0.028 \\
\hline$\overline{\mathrm{CHF} * \star}$ & $\begin{array}{l}\text { Yes } \\
\text { No }\end{array}$ & $\begin{array}{c}7 \\
32\end{array}$ & $\begin{array}{c}19.44 \% \\
6.78 \%\end{array}$ & $\begin{array}{c}29 \\
440\end{array}$ & $\begin{array}{l}80.56 \% \\
93.22 \%\end{array}$ & 0.006 \\
\hline Peritonitis & $\begin{array}{l}\text { Yes } \\
\text { No }\end{array}$ & $\begin{array}{c}7 \\
32\end{array}$ & $\begin{array}{c}15.56 \% \\
6.91 \%\end{array}$ & $\begin{array}{c}38 \\
431\end{array}$ & $\begin{array}{l}84.44 \% \\
93.09 \%\end{array}$ & 0.037 \\
\hline Intestinal obstruction & $\begin{array}{l}\text { Yes } \\
\text { No }\end{array}$ & $\begin{array}{l}13 \\
26\end{array}$ & $\begin{array}{c}14.13 \% \\
6.25 \%\end{array}$ & $\begin{array}{c}79 \\
390\end{array}$ & $\begin{array}{l}85.87 \% \\
93.75 \%\end{array}$ & 0.010 \\
\hline Haemodynamic instability & $\begin{array}{l}\text { Yes } \\
\text { No }\end{array}$ & $\begin{array}{c}9 \\
30\end{array}$ & $\begin{array}{c}20.45 \% \\
6.47 \%\end{array}$ & $\begin{array}{c}35 \\
434\end{array}$ & $\begin{array}{l}79.55 \% \\
93.53 \%\end{array}$ & $<0.001$ \\
\hline
\end{tabular}

observed and treated in 44 patients $(8.66 \%)$, and was the main indication for vasopressors or inotropes use. We found that patients with this type of pre-, intra- and post-operative treatment develop AL more often, compared with hemodynamically stable patients $(20.45 \%$ vs $6.47 \%)(\mathrm{P}<0.001)$.

AL occurred in $21.57 \%$ of patient with obesity (11 cases) versus $6.13 \%$ in patients without obesity ( 28 cases) $(\mathrm{P}<0.001)$.

Acute or chronic kidney diseases was found in 28 cases (5.51\%), without significant difference between sexes $(\mathrm{P}=0.55)$. In 9 of 39 cases of AL, patients were diagnosed with kidney insufficiency (23.08\%). AL occurred in $32.14 \%$ (9 cases) of patients with renal diseases and in $6.25 \%$ of patients without this type of pathology (30 cases) $(\mathrm{P}<0.001)$.

These data, presented above, were summarized in Table 2.

Identifying those factors we propose a risk evaluation score, based on 12 of them: eight associated pathologies or personal pathological histories, two clinical and imagistic variables (intestinal obstruction, peritonitis) and two therapeutical variables (necessity of blood transfusion and/ or vasopressors).

To temper the effect of OR and to make measures symmetrically, the weight of every risk factor was calculated as natural logarithm of OR, - noted with "k" (Table 3).

The total score was calculated as sum of " $k$ " coefficient for every present risk factor:

The minimal possible score is 0 points (if there are no risk factors) and the maximum possible is 16.22 points.

The mean score in our study group was $1.84 \pm 1.89$ points, with 0 points minimal and 11.12 points maximum values. In AL patients' group, the mean score was $5.06 \pm 1.95$ points, and in AL-free patients' group $-1.57 \pm 1.61$ points.

The optimal cut-off value was determined using the Younden's index and accuracy. For a cut-off value of 4 points, the sensibility of the 
Table 3. Risk factors included in FISTULA SCORE and value of weight ( $k$ ) used for risk quantification

\begin{tabular}{lcclcc}
\hline Variables & $\mathbf{O R}$ & $\mathbf{k}$ & Variables & $\mathbf{O R}$ & $\mathbf{k}$ \\
\hline Presence of obesity & 4.21 & 1.44 & Presence of spreaded cancer & 3.64 & 1.29 \\
\hline Presence of heart arrhythmia & 3.91 & 1.36 & Presence of congestive heart failure & 3.32 & 1.20 \\
\hline Presence of diabetes & 3.28 & 1.19 & Blood transfusion need & 4.43 & 1.49 \\
\hline Presence of liver pathologies & 2.80 & 1.03 & Vasopressors need & 3.72 & 1.31 \\
\hline Presence of renal disease & 7.11 & 1.96 & Presence peritonitis & 2.48 & 0.91 \\
\hline Presence of atherosclerosis & 8.51 & 2.14 & Presence of intestinal obstruction & 2.47 & 0.90 \\
\hline
\end{tabular}

score is $79.5 \%$ and the specificity is $90.2 \%$, with a predictive positive value of $40.26 \%$, predictive negative value of $98.14 \%$, and accuracy of $89.4 \%$. ROC curve based on risk points can be found in Graphic 1.

We named this preoperative risk quantification system "FISTULA SCORE", acronym result from: Fat (obesity), Irregular heartbeat (arrhythmias), Sugar (diabetes), Transfusion need, Untouchable abdomen (peritonitis), Liver pathologies, Atherosclerosis, Spreaded cancer (presence of distant metastasis), Congestive heart failure, intestinal Obstruction, Renal failure, Epinephrine need (hemodynamic instability).

\section{Discussion}

AL remain a serious complication in digestive surgery, increasing the length of stay and associated costs, affecting the overall survival rate, delaying the start of adjuvant treatment, involving sometimes different complex thera-

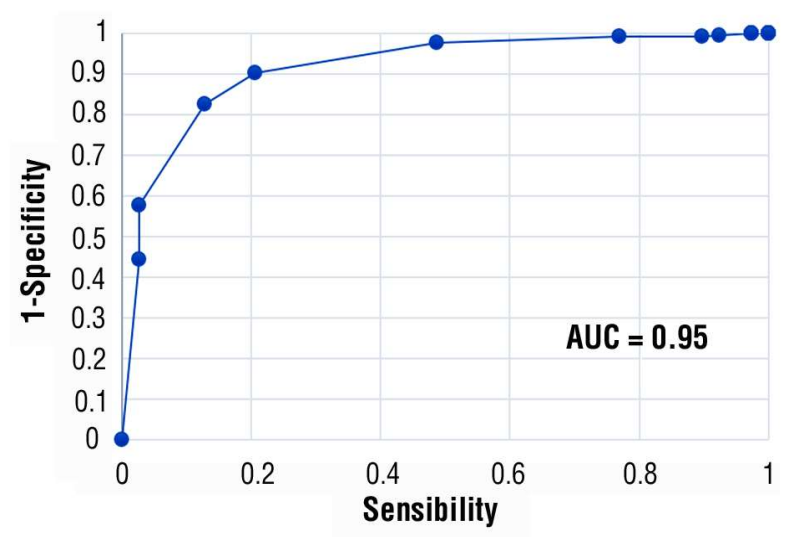

Graphic 1. ROC curve for FISTULA SCORE peutic strategies and emotionally affecting not only the patient, but also the surgeon and all medical staff (13-16).

Identifying risk factors in every patient is mandatory, but not enough to assess the risk of AL, especially in those with more than one. The presence of multiple associated conditions favorable for AL return a final risk, different from the simple sum of risks, even if it is necessary to apply a complex formula.

There are a lot of other negative factors identified in this study or in others $(17,18)$, not included in this proposed score. We demonstrated the impact of hypocalcemia on AL in a smaller group of patients, even if the complete pathophysiological mechanism is unclear and the causes of hypocalcaemia can be various.

Anemia and other disorders linked to renal diseases can't be separate from other causes (18-21) and were studied as independent risk factors, as well as pathologies affecting renal function (22). The differences between eGFR, hemodialyzed and non-hemodialyzed subgroups wasn't been studied, even if it was known that first group of patients are predisposed to chronic inflammation (23) and transmissible diseases (24) and can have a poorer outcome.

Our score (FISTULA SCORE) was based on attributed risks found in our study group for each factor and has the purpose to identify patients at risk for $\mathrm{AL}$ and, in some cases, to change the therapeutic or surgical strategy (diverting stoma). Using FISTULA SCORE preoperatively, even an unexperienced surgeon can choose between a surgical strategy implying an anastomosis or a Hartmann's procedure (5).

This score has a good sensibility, specificity 
and predictive negative value, but a low predictive positive value. By applying this score, it is important to consider risk-benefit assessment.

For practical benefits, larger studies are required and other identified risk factors can be included.

\section{Conclusions}

AL have multifactorial aethiology and not all the factors are known yet. The risk for AL must be appreciated and quantified with a multivariable scoring system.

FISTULA SCORE can identify, with a good statistical significance, patients at risk for AL, changing the case management, reducing length of stay, costs, morbidities, mortality and psychological effects on patient and medical stuff.

\section{Authors' Contribution}

CB, DS, DG designed the study, performed the literature search and selected the included studies, performed statistical analysis and interpretation of the results. CB wrote the paper. IA, DV critically revised the manuscript. All authors read and approved the final version of the manuscript.

\section{Availability of Data and Materials}

The used and/or analyzed data sets during the present study are available from the author on reasonable request.

\section{Conflict of Interest}

The authors declare no conflict of interest.

\section{Ethics Approval and Consent to Participate}

This study was approved by Ethics Committee of the Emergency University Hospital of Bucharest (Romania) (approval no. 50706/ 08.10.2020). Written informed consent was obtained from the patients prior to publication.

\section{References}

1. Alecu L, Tulin A, Enciu O, Bărbulescu M, Ursuț B, Obrocea F. Gastrointestinal Stromal Tumors - Diagnosis and Surgical Treatment. Chirurgia 2015;110(6):525-9.

2. Spataru RI, Sirbu A, Sirbu, D. Forensic ramifications in diagnosing and treating high forms of the Hirschsprung's disease. Rom J Leg Med 2013; 21(2):105-110

3. Li YW, Lian P, Huang B, Zheng HT, Wang MH, Gu WL, et al. Very Early Colorectal Anastomotic Leakage within 5 Post-operative Days: a More Severe Subtype Needs Relaparatomy. Sci Rep. 2017;7:39936.

4. Park JS, Huh JW, Park YAh, Cho YB, Yun SH, Kim HC, et al. Risk Factors of Anastomotic Leakage and Long-Term Survival After Colorectal Surgery. Medicine (Baltimore). 2016 ;95(8):e2890.

5. Doran H, Pătrașcu T, Catrina E, Mihalache 0. Hartmann 's procedure. A 30 years one-centre clinical experience. Chirurgia (Bucur). 2008;103(4):413-6.

6. $\mathrm{Wu}, \mathrm{Z}$. et al. Is the intraoperative air leak test effective in the prevention of colorectal anastomotic leakage? A systematic review and meta-analysis. Int J Colorectal Dis. 2016;31(8):1409-17.

7. Midura EF, Hanseman D, Davis BR, Atkinson SJ, Abbott DE, Shah SA, et al. Risk factors and consequences of anastomotic leak after colectomy: a national analysis. Dis Colon Rectum. 2015;58(3):333-8.

8. Telem DA, Chin EH, Nguyen SQ, Divino CM. Risk Factors for Anastomotic Leak Following Colorectal Surgery: A Case-Control Study. Arch Surg. 2010; 145(4):371-376.

9. Kryzauskas M, Bausys A, Degutyte AE, Abeciunas V, Poskus E, Bausys R, et al. Risk factors for anastomotic leakage and its impact on long-term survival in left-sided colorectal cancer surgery. World J Surg Oncol. 2020;18(1):205.

10. Arezzo A, Migliore M, Chiaro P, Arolfo S, Filippini C, Di Cuonzo D, et al. The REAL (REctal Anastomotic Leak) score for prediction of anastomotic leak after rectal cancer surgery. Tech Coloproctol. 2019;23(7):649-663.

11. Yang SU, Park EJ, Baik SH, Lee KY, Kang J. Modified Colon Leakage Score to Predict Anastomotic Leakage in Patients Who Underwent Left-Sided Colorectal Surgery. J Clin Med. 2019;8(9):1450.

12. Rojas-Machado SA, Romero M, Arroyo A, Rojas-Machado A, López J, Calpena R. Anastomic leak in colorectal cancer surgery. Development of a diagnostic index (DIACOLE). Int J Surg. 2016; 27:92-98.

13. Qu H, Liu Y, Bi D-S. Clinical risk factors for anastomotic leakage after laparoscopic anterior resection for rectal cancer: a systematic review and meta-analysis. Surg Endosc. 2015; 29:3608-3617.

14. Den Dulk M, Marijnen C, Collette L, Putter H, Pțhlman L, Folkesson J, et al. Multicentre analysis of oncological and survival outcomes following anastomotic leakage after rectal cancer surgery. Br J Surg. 2009;96(9): 1066-75.

15. Ptok H, Marusch F, Meyer F, Schubert D, Gastinger I, Lippert H, et al. Impact of anastomotic leakage on oncological outcome after rectal cancer resection. Br J Surg. 2007;94(12):1548-54.

16. Avino A, Jecan CR, Cozma CN, Balcangiu-Stroescu AE, Bălan DG, Ionescu $D$, et al. Negative pressure wound therapy using polyurethane foam in a patient with necrotizing fasciitis, Mater Plast. 2018;55(4):603-605.

17. Georgescu MT, Moldoveanu V, Ileanu B-V, Anghel R. Dosimetric influence of uterus position in cervix cancer high-dose-rate brachytherapy. Romanian J Phys. 2016;61:1557-1566.

18. Georgescu D, Patrascu T, Georgescu T, Tulin A, Mosoia L, Bacalbasa N, et al. Diabetes Mellitus as a Prognostic Factor for Locally Advanced Rectal Cancer. In Vivo. 2021;35(4):2495-2501.

19. Timofte D, Dragos D, Balcangiu-Stroescu AE, Tanasescu MD, Balan DG, Raducu $\mathrm{L}$, et al. Characteristics of patients at initiation of renal replacement therapy - experience of a hemodialysis center. Exp Ther Med. 2020;20(1): 103-108.

20. David C, Bover J, Voiculet C, Peride I, Petcu LC, Niculae A, et al. Coronary risk score for mineral bone disease in chronic non-diabetic hemodialysis patients: results from a prospective pilot study. Int Urol Nephrol. 
2017;49(4):689-700. Epub 2016 Dec 18.

21. Lupușoru M, Lupușoru G, Ailincăi I, Frățilă G, Andronesi A, Micu E, et al. Renal replacement therapy in cancer patients with acute kidney injury (Review). Exp Ther Med. 2021;22(2):864. Epub 2021 Jun 11.

22. Dragoș D, Manea MM, Timofte D, Ionescu D. Mechanisms of Herbal Nephroprotection in diabetes mellitus. J Diabetes Res. 2020;2020:5710513. eCollection 2020.
23. Stroescu A, Tănăsescu M, Diaconescu A, Răducu L, Bălan D, Ionesc D. A Brief Presentation of the Characteristics of Hemodialysis Membranes. Mater Plast 2018;55:332-334.

24. Timofte $D$, Dragos D, Balcangiu-Stroescu $A E$, Tănăsescu MD, Bălan DG, Avino A, et al. Infection with hepatitis $C$ virus in hemodialysis patients: An overview of the diagnosis and prevention rules within a hemodialysis center (Review). Exp Ther Med. 2020;20(1):109-116. 